\title{
Correction: Abstracts from international Emergency Medicine journals
}

Abstracts from international Emergency Medicine journals. Emerg Med J 2019;36:511-3. 10.1136/emermed-2019-208938.

In this article under the journal Annals of Emergency Medicine, the title and author list was incorrect. The details were duplicated from the African Journal of Emergency Medicine. The Annals abstract title and author list should have read as follows:

Is the Mallampati Score Useful for Emergency Department Airway Management or Procedural Sedation?

Steven M Green, Mark G Roback

(C) Author(s) (or their employer(s)) 2019. No commercial re-use. See rights and permissions. Published by BMJ.

Emerg Med J 2019;36:e1. doi:10.1136/emermed-2019-208938corr1

A) Check for updates 